Post-print of 'Kharchenkova, Svetlana (2018). "The Market Metaphors: Making Sense of the Emerging Market for Contemporary Art in China," Poetics, 71, 71-82,' published by Elsevier and available online at https://doi.org/10.1016/j.poetic.2018.06.001.

\title{
The Market Metaphors: Making Sense of the Emerging Market for Contemporary Art in China
}

\author{
Svetlana Kharchenkova
}

This article proposes a novel approach to studying markets through metaphor. Unlike other sociological studies of market emergence, it focuses on emic perceptions and their consequences for actions in an emerging peripheral market. By analysing a guiding conceptual metaphor for the contemporary art market in China it investigates how market actors make sense of their market and its global position. It draws on 125 in-depth interviews and observations conducted in Beijing in 2012-2014. The market is conceptualised as an organism and juxtaposed to "mature" Western markets. This metaphor enables China's market actors to (a) describe the market, (b) justify illegitimate behaviours, and (c) see the future and the possible ways of action. This study contributes to the sociology of markets as it suggests applying metaphor analysis to markets, as well as theorising non-agentic elements of market construction and focusing on the time dimension of market emergence. It contributes to globalisation literature as it discusses the perception of globalisation in a peripheral market, and suggests that this market's participants do not self-Orientalise.

\section{Introduction}

In recent decades cultural meanings and symbolic systems have been receiving increasing attention in sociology, including studies of markets and economic processes (Abolafia, 1996; Velthuis, 2005; Zelizer, 1979). In particular, metaphors have been used to empirically gauge social meanings and understandings of social configurations (Alexander, 1990; Heino et al., 2010; Ignatow, 2003; Lakoff and Johnson, 1980; Patriotta and Brown, 2011). Although metaphors have been an object of extensive study in organisational and entrepreneurship research (Cardon et al., 2005; Cornelissen et al., 2008; Dodd, 2002), they have not been used to study markets (Fligstein and Dauter, 2007). This article focuses on a conceptual metaphor for a market that recently emerged in China. It does so to investigate the perceptions and resulting actions of participants of a new market outside the Euro-American context. 
Sociological studies of market emergence tend not to focus on emic understandings of this process. However, as markets emerge around the world, making sense of developments is arguably central to the experiences of such markets' participants (Anand and Peterson, 2000; Zelizer, 1979). By focusing on sensemaking in a new unsettled market, this article advances sociological approaches to studying emerging markets and their position on the global stage. This article asks: how are (new) markets understood by their actors? Why do their actors act (or not) in certain ways regarding their creation? Do they perceive them as changing, as different from existing markets? How do they make sense of their market's relative position?

To investigate how market actors understand their market and how and why they act in it, I build on the conceptual metaphor theory by Lakoff and Johnson (1980). Metaphors are not limited to poetic language; language generally is metaphorical (Klamer and Leonard, 1994; Lakoff and Johnson, 1980; McCloskey, 1995). Conceptual metaphors are mappings across conceptual domains and are manifested in linguistic metaphors and regular expressions (Lakoff and Johnson, 1980). An example of a conceptual metaphor is "love is a collaborative work of art" (Lakoff and Johnson, 1980). It is manifested in linguistic metaphors (e.g. "love is an aesthetic experience") and regular expressions (e.g. "love involves shared responsibility"). Metaphors not only reflect or represent reality, but also organise the social world and shape our understanding of it (Klamer and Leonard, 1994; Lakoff and Johnson, 1980; McCloskey, 1995). The focus on conceptual metaphors is productive because they reveal taken-for-granted ideas, shared understandings and motivations for actions (Lakoff and Johnson, 1980; Urry, 2000: 21). Conceptual metaphors, such as "love is a collaborative work of art", not only help to make experiences coherent, and help to make sense of them, but also have implications for behaviour (Lakoff and Johnson, 1980: 139-142).

By providing a detailed analysis of shared understandings of the market, the approach adopted in this paper draws attention to the role of cognition in market emergence. Salience of cognitive and symbolic systems has been emphasised by scholars of institutions and organisations (Powell and DiMaggio, 1991; Lounsbury et al., 2003; Scott, 2001; Suddaby et al., 2010), and the cultural approach has been applied in sociology of markets (Abolafia, 1996; Beckert, 2010; Velthuis, 2005; Zelizer, 1979). Neo-institutionalists agree that symbols reflect cultural frameworks and shape meanings as they are employed to make sense of reality (Scott, 2001: 57). According to them, symbolic systems and cognitive frames not only organise the social world, they also guide behaviour, as they serve as the basis for norms and rules. Shared taken-for-granted scripts (Meyer and Rowan, 1977) or "conceptions of control” (Fligstein, 2001) direct action. The "markets as culture" perspective also emphasises the importance of 
culture (shared systems of meaning) for action in markets. Studies of markets have looked at how actors make sense of market dynamics (Komarova, 2017). Despite the recognition of the link between conceptual, linguistic and action levels in studies of markets, institutions and organisations, metaphors have not been used in market research, which makes this approach innovative.

I focus on China's contemporary art market, which is a case of a newly emerged market, because its first organisations appeared in the 1990s. It is an especially interesting case, because its emergence is closely linked with foreign markets, and because it has been developing rapidly to become one of the world's largest, with hundreds of active galleries and auction houses (McAndrew, 2014). Relying on 125 in-depth interviews and long-term observations in the Beijing art market, I argue that a central conceptual metaphor for this market among its participants is "an organism". In what follows, I present entailments and implications of this conceptual metaphor, I show how it is used, and how it works. In doing so, I emphasise complexity pertinent to metaphors (Lakoff and Johnson, 1980: 12-13). I show that apart from serving a descriptive purpose, this conceptual metaphor enables market actors to compare their market with the "Western" markets and to justify illegitimate behaviours. The metaphor also highlights what should (not) be done about the market's development: it inspires market actors to be passive and act as learners and educators, and enables them to imagine the market's future. This study has implications for market sociology, as it draws attention to the actors' passivity in market emergence and change, suggesting a departure from the dominant focus on agency in sociological studies of market emergence (Fligstein, 2001). It also highlights how a peripheral market's participants position themselves vis-à-vis hegemonic markets (Fabian, 1983; Said, 1978).

\section{Data and methods}

This article is based on the analysis of 125 semi-structured interviews with participants in the Chinese contemporary art world. Interviews were conducted during the period 2012-2014, mostly ( $n=120)$ in Beijing, with artists $(n=35)$, art dealers/gallerists $(n=44)$, collectors $(n=12)$, representatives of auction houses $(n=9)$ and art fairs $(n=5)$, art critics, curators, museum directors/managers $(n=11)$, and other Chinese art world participants, such as art journalists, art fund managers and others $(n=9) .{ }^{1}$ All my interviewees worked with contemporary art. This research focused on contemporary art rather than traditional ink-wash

\footnotetext{
${ }^{1}$ Some interviewees had several roles, in these cases they are classified here by their dominant role.
} 
paintings, calligraphy or antiques, because of its international connection and newness in China. All the interviewees were either based in mainland China (most interviewees) or spent significant time there annually. The majority were from mainland China $(n=105)$, others (primarily art dealers, art fair organisers, and curators) were originally from Taiwan, the USA, Italy, the Netherlands, Australia and other countries $(n=20)$. The high percentage of foreigners reflects the Chinese contemporary art world's internationalisation. The Beijing contemporary art world has grown rapidly in the last decades, and numbers over a hundred commercial contemporary art galleries and several art fairs. It is also home to dozens of auction houses, some of which are among the world's largest in terms of sales turnover. Many contemporary artists move to Beijing from the rest of the country to develop their careers. My sample is characterised by variety in terms of age, sex, international experience and exposure, commercial and artistic success, extent to which they contributed to marketbuilding, and time they had been active in the market. It includes internationally famous artists and gallerists, and China's largest auction houses, as well as lesser-known, novice market actors. Respondents were recruited by combining targeted sampling, approaching art world actors randomly at art events and gatherings, and multiple-entry snowballing. The interviews concerned respondents' concrete practices and experiences in the market.

The topic of participants' understanding of their market development and relationship with other markets was arrived at inductively during fieldwork as many respondents commented on this. Interviewees often generalised about China's market, its participants and their behaviours, and this article focuses on such general statements. I understand the market as a field constituted by actors, their practices and understandings (cf. DiMaggio and Powell, 1983; Fligstein, 2001). This was also an important way in which my interviewees saw their market, which is crucial, as my focus is on the emic perspective. I did not analyse instances when interviewees distinguished between "mature" and "immature" local actors, such as art galleries, which is common in art markets elsewhere. Instead, I analysed instances when, for example, Chinese galleries were labelled "immature" overall. I was not interested in statements about price fluctuations ("the market is recovering"), because they concern prices rather than market structure, actors or their practices. As the focus is on the market, I was not interested in statements about artistic quality ("his art is still immature").

The conceptual metaphor emerged from the data: interviews were transcribed and coded inductively, which allowed me to identify linguistic metaphors and a central conceptual metaphor. Not all interviewees were eloquent speakers who used many linguistic metaphors. Expressions that I consider to be surface manifestations of a central conceptual 
metaphor are linguistic metaphors ("young" market) and literal statements (the market "has existed for a short time") that fit the conceptual domain (Lakoff and Johnson, 1980: 139-140). For example, although the English speakers referred to the market as "young", the Chinese speakers used literal statements with the same meaning. Including literal statements allowed me to deal with the fact that the interviews were conducted in languages with different underlying conceptual systems: Mandarin $(n=105)$, English $(n=15)$ and Dutch $(n=2)$ and Mandarin/English ( $n=3){ }^{2}$ After the conceptual metaphor emerged in the first round of coding, I marked interviews on whether the metaphor had surface representations in them. To be marked positive, an interview had to contain several linguistic metaphors or nonmetaphorical expressions applied to the market, behaviours or players overall, that fit the relevant conceptual domain. The conceptual metaphor had surface representations in a significant percentage of interviews.

Since the study developed inductively and the interviewees were not probed for metaphors, the fact that some interviewees did not make certain statements or did not even talk about the market in general, does not mean they do not hold a particular view. I asked some respondents whether they considered the Chinese market "immature" at the end of the interview, and they said they did, even though this did not emerge naturally during the interview (in such cases I did not count the interview as containing the conceptual metaphor). A limitation of an inductive approach is that it does not allow us to draw hard conclusions about, for example, among which types of actors the conceptual metaphor is most prevalent.

Interview data were supplemented by observations at art world events, including gallery and museum openings, auctions and auction previews, art fairs, artists' gatherings, etc., conducted over ten months during the period 2012-2014. These allowed me to observe public discussions about the market and actual market-building behaviour. Additionally, several dozen interviews with foreign dealers and collectors based in Europe, and Chinese artists and intermediaries involved in the more traditional art circles, helped contextualise the findings.

\section{Market metaphors}

Outwardly the Chinese art market infrastructure is similar to art markets elsewhere: it consists of commercial galleries, auction houses, art fairs, biennales, museums, art critics and others. Yet, during my fieldwork it became clear that the Chinese art market actors perceived

\footnotetext{
${ }^{2}$ All translations are mine.
} 
their local market as different. A dominant way in which China's art market actors conceptualise their market and its participants is as a young, developing organism: a plant, a fruit or vegetable, an animal or a child. Sometimes it is clearly conceptualised as a child, other times it is unclear what organism is implied. Markets are also perceived as "alive" outside of China, exemplified by expressions like "the market is jumpy" (Aspers, 2011: 88). In China, however, the concerns are with the development of the overall market rather than (only) market fluctuations. My respondents make sense of their market by contrasting it with imagined "Western" markets. Art markets are seen as organisms that mature over time. This conceptual metaphor is well reflected, for example, in the following quote by a mainland Chinese gallery owner who founded his gallery in 2005, and has worked in the art world even longer:

"[European galleries are in] a totally different art market. China is just starting up. It's very young. This market is not very mature. Not very healthy. Starting from [a] low point. From [a] very low point. But [the] European market has been [there] for centuries. It's very mature, healthy, it's quite different." (I28)

The conceptual metaphor of an organism came out strongly from the data. I found its metaphorical and non-metaphorical linguistic representations in over $65 \%$ of my interviews. Table 1 presents the dichotomous nature of metaphorical and literal expressions used by the market actors.

Table 1. Metaphorical and non-metaphorical linguistic expressions.

\begin{tabular}{|l|l|}
\hline The Chinese market & The "Western" markets \\
\hline immature & mature \\
\hline unhealthy & healthy \\
\hline young & existing for a long time \\
\hline irregular, messy & standard \\
\hline short-term thinking & long-term thinking \\
\hline ignorant & knowledgeable \\
\hline inexperienced & experienced \\
\hline unprofessional & professional \\
\hline abnormal & normal \\
\hline bad & good \\
\hline
\end{tabular}


None of the interviewees called the Chinese market "mature" or "standardised". Instead, they routinely referred to it as "immature" and "messy". The linguistic metaphor “(im)mature", for example, was used unprompted by respondents to talk about their market, practices, and behaviours, or, for example, galleries in general, in approximately $35 \%$ of my interviews. ${ }^{3}$ Several respondents claimed that China's problems could also be found in "Western" markets, but such responses were rare exceptions. This ubiquity reveals that this art market's participants are concerned with the market's development and behaviours, as well as its position vis-à-vis other markets. It is also interesting, because in emerging markets or fields few shared understandings are expected (Fligstein and McAdam, 2012). Yet, the conceptual metaphor was easily identified, suggesting that this market has formed to an extent.

As the table shows, the expressions have a moral dimension. Many interviewees talked at length about "bad" local behaviours. According to them, in China, short-term and profit-oriented thinking prevails. The broader public and collectors are ignorant about contemporary art. Many collectors buy for investment and status, not because they love art, and speculators abound. ${ }^{4}$ Counter to international conventions, artists sell directly to buyers from the studio instead of through art dealers. Trust and long-term ties between gallerists and artists are lacking. Prices at galleries and artists' studios are perceived as random, and auction prices as artificially inflated. Some Chinese artists cooperate directly with auction houses, which is regarded as an illegitimate practice internationally, because it is considered overly commercial. Independent and trusted museums and art critics are lacking. Museums rent spaces to artists, curators include their artist-friends in shows and critics write favourable reviews for their friends. This complicates establishing and judging the artistic value, which exacerbates uncertainty in the market. According to my interviewees, in China (potential) collectors, galleries, auction houses and artists do not know how to behave "properly" and are ignorant about the morals of art markets (cf. Fourcade and Healy, 2007). Some actors have strong normative ideas about how market actors should function, and think China's art market does not meet these standards. As an auction house oil paintings department manager with few ties to Western markets said:

"I think we should [...] slowly develop normal [practices]. This is just a transition period [...]. I believe in the European and American standard. I hope the Chinese

\footnotetext{
${ }^{3}$ This number does not include multiple instances where the metaphor is applied to distinguish "mature" and "immature" Chinese players.

${ }^{4}$ Treating artworks as if they are luxury products was mentioned as being problematic only twice.
} 
market will be like those in Europe and the US, everyone has their own role, it's very sound." (I99)

In contrast, "Western" markets are perceived to be driven by artistic and aesthetic motives. Respondents idealise foreign markets, although many are unclear about their functioning. One artist, for example, thought it was illegal to auction artworks by young artists in "the West", a practice that is frowned upon but legal internationally. Some gallerists and museum managers thought that all "Western" children visit museums, every family owns artworks, and that many foreign galleries "have existed for several hundred years" (Chinese collector and gallery owner, I18), which are all exaggerations. Similarly to scholars who compare Chinese empirics with ideal-typical concepts (Guthrie, 1999: 179), the Chinese art market participants compare their empirical reality with ideal-typical "Western" markets.

This conceptual metaphor was most prominent, but not the only one. China's art market has ontological correspondences with different conceptual domains, what Lakoff (1993) called "simultaneous mappings" (cf. Lakoff and Johnson, 1980: 41-51). Using different metaphors for one concept is normal, because social reality is complex. Other conceptual metaphors for the market, that can also be found outside China's context, include: the market as a building (which you "build"), a system ("structured", with "own internal logic"), a playing field (with "rules of the game") etc. Such different metaphors sometimes occurred in the same interview. In addition, we find China- and time-specific novel metaphors, that are related to the situation in Beijing during my fieldwork. For instance, the unfavourable policy environment in which the market was situated, was compared to Beijing's heavily polluted air.

The organising metaphor only highlights certain aspects of the market. Mappings across conceptual domains are asymmetric and partial (Lakoff, 1993; Lakoff and Johnson, 1980: 52-55). Metaphors accentuate important experiences and make them coherent, while they mask other experiences (Lakoff and Johnson, 1980: 142). Only some parts of the source domain "organism" are used to structure the concept of China's contemporary art market. As Lakoff and Johnson (1980: 33-34) pointed out, personification can focus on different aspects. The focus here is not the market's holistic character, anatomy or physiology, nor the friendly or hostile relationships among art markets. The market participants' take on the metaphor is such that they are not concerned with market mortality or finite life cycle. Instead, the metaphor highlights the development aspect. As I show below, the metaphor inspires market 
participants to act in accordance with it: it helps describe and explain behaviour, it highlights the problems and helps envision and organise the future.

\section{How metaphors affect action}

\subsection{Description}

The conceptual metaphor affects how market actors communicate as it provides language to talk about their market. This happens at several levels. The conceptual metaphor functions in a complex way. First, market participants do not only apply the linguistic metaphors "young", "immature", and "healthy" to the "market" generally, but also to organisations (galleries, auction houses, etc.), to individuals (artists, collectors, art critics, etc.), to their behaviours in the market and to themselves. I consider these expressions to be surface representations of the same conceptual metaphor that applies to the whole market, including participants and their behaviours, because of implied interconnectedness: "immature" actors constitute an "immature" market, "unhealthy" behaviours result in an "unhealthy" market. Market actors and the market are understood similarly. This, in turn, indicates that for Chinese art market participants, the market not only assumes the qualities of an organism, but also is perceived to be tightly linked with those who constitute it, with their interactions in this market and with the market environment, which is also perceived as immature and not conducive to mature behaviour. Respondents link the environment's immaturity not only to the "age" of the market (actors), but also to the lack of laws and regulations.

Second, market participants do not refer to all Chinese market actors as equally "immature". Some have been in this market longer and are perceived to be more "mature" than others. This is similar to the art worlds in Europe and the USA, where linguistic metaphors of maturity, youth and the domain of family (but not necessarily health) are common: artists, artworks, artistic styles and collectors can be referred to as "young" or “mature” (Bourdieu, 1993; Plattner, 1996: 106, 230; Velthuis, 2005: 55). In China such language is not only applied to categorise and draw boundaries (Lamont, 1992), but also to generalise about the market overall. Some admit they lack experience; because they see the whole market as "young", they consider themselves "young" as well. Respondents perceived immaturity as pervasive, for example, galleries did not only call other galleries, but also 
artists, collectors and their behaviours, and the market environment "immature" and "unhealthy" compared with other markets.

\subsection{Explanation and justification}

The metaphor affects how market actors view and justify themselves and others. Art market participants have ideas about what constitutes good and bad behaviour (Velthuis, 2005: 42-45). In China, the morals of markets are not only about appropriate behavioural norms within China's market, but are also defined according to perceived international conventions. Due to the conceptual metaphor, "Western" markets are not viewed as good because they are inherently "standard" - according to my interviewees, the problems, such as auction manipulations, also happened in "the West" early on - but because they have been time-tested. For China's art market actors, the morality of the market is age-related: unlike "Western" markets, the inexperienced Chinese market has not yet figured out the moral way (Fourcade and Healy, 2007). To put this into neo-institutional terms, behaviours in older markets are viewed as more legitimate (DiMaggio and Powell, 1983). The Chinese market and its actors' behaviours are presented as "messy" because they have existed for a short time. As markets are conceptualised as organisms, markets are seen as equally important, just of different age. As a mainland dealer said, whose gallery takes part in art fairs internationally: "...foreign museums are trusted because they have extremely serious art evaluation standards and many years of experience [...] in China this hasn't formed yet." (I34)

This conceptualisation reminds one of the sensemaking of international relations. Lakoff (2003) showed that nations are seen as persons, and developing countries as children, who all want to be healthy. Similarly, the mainland market is seen as a new, growing-up member among the national art markets, as less mature than the Taiwanese or Hong Kongese markets. "The West" is a reference point also for the Taiwanese and Japanese galleries active in China. A young Chinese gallery employee with no international experience made the conceptual metaphor explicit:

"It can't mature within a few years, that's just how it is. So China's art market, you can just say, it's a little child, right, compared with the European ones. Because they've already existed for many decades." (I46)

This metaphor generates expectations. It allows market participants to understand and justify their own and others' "bad" behaviours, and their market's positioning among other markets. Many perceive idiosyncrasies as stemming from the early developmental stage: one 
should not have excessive expectations of "young", inexperienced participants in a "young" market. ${ }^{5}$ A mainland Chinese dealer running a well-respected commercial gallery, explained why exclusive gallery representation system does not work in China:

"The Chinese art market is irregular. It's probably different from Europe [...] of course, we have problems here in China, because the Chinese contemporary art market's [history] is very short. It's only been thirty something years. And in addition, in this process, a lot of organisations are not very mature." (I24)

Fellow market actors are often conceptualised as children, naïve and clueless. An experienced Taiwanese gallerist explained why he does not bring challenging conceptual art to the mainland:

“... [for] these mainland Chinese who have just become rich, and haven't really been exposed to art, it's really too difficult, I think. They've only learned to crawl, and you want them to run or even fly. I think it's way too difficult." (I14)

China's market is seen as too "young" to fully imitate international practices, as the local environment is presented as not conducive to good behaviours. According to my Chinese respondents, even foreigners, who know the "proper" conventions, struggle to apply their practices in China.

Poor health is perceived to result from bad behaviours, such as speculation, and lack of art knowledge. Auction houses were singled out by some as a reason for the market's poor health. A gallery manager active only in the mainland said:

"The Chinese auction market is very unhealthy. It's a process of accelerated ripening. Like when you use pesticide to grow fruit so that it grows quicker, auctions accelerated the development of the Chinese art market". (I10)

Overall, however, bad practices and ignorance are not blamed on any particular (groups of) actors. For example, counter to the international conventions, many artists cooperate with commercial galleries per exhibition rather than being affiliated with one gallery. My respondents considered this the fault of artists, unprofessional galleries, collectors, auction houses, the lack of independent museums, etc.

Actors conceptualise their market as being located in a "bad" environment not only because many are immature and have bad practices, but also because the government did not create good conditions for not-for-profits such as art spaces or museums, favourable tax policies, or contemporary art education at schools. They perceive the possibility of regulation

\footnotetext{
${ }^{5}$ Some respondents explained the perceived differences by China's cultural uniqueness. However, this explanation was not common.
} 
as positive and disciplining: many said that the government should stimulate contemporary art market development by, for instance, facilitating the establishment of museums collecting contemporary art, providing tax breaks, and other preferential policies. Art dealers established a gallery association in 2011 to lobby the government, but many were sceptical about its effects. During my fieldwork understanding of the market development was not defined by the state's control over artistic production. This contrasts with the persisting emphasis on censorship and other government restrictions in "Western" media and academic literature on Chinese art and the art world.

What needs to be done for a good healthy market to develop? As an art fair director passionately told me, "what we need is time, what we need is education" (I112). Many in the Chinese art world would agree.

\subsection{Highlighting the future and possible ways of action}

The "organism" metaphor highlights shortcomings in the market, and suggests that some problems are stage-related, while others can be corrected. It inspires market actors to be patient and let the market mature. It implies that the change does not have to result from strategic behaviour, the market will evolve naturally at its own pace, it will improve as its participants accumulate knowledge and experience.

A temporal dimension is central to my respondents' understanding of their market. A collector said:

"There's no need to hurry. The Western gallery system has been developing for so many years, and here in China it has been just over ten years. So I think we should view it as normal: you cannot grow fat from one bite, and reach Western standards in one go. To reach the level of Western galleries you clearly need time, and more serious gallerists." (field notes 03.05.2013)

Many interviewees, ranging from the first and central market actors to relative newcomers saw market improvement as a "slow", "gradual”, "step by step" process. In an office in his white cube space, similar to galleries in Europe and the USA, an energetic gallerist, aged 36, lamented the lack of respected museums:

“...this really can only be resolved with time. Nothing you can do at all. Only time will help. I hope when I am old, old... it would be great if it is resolved by the time I am fifty." (I34) 
Others - artists, curators, dealers, art fair organisers - volunteered time-frames for various market aspects to improve ranging from "in a few years" time" to "at least 20 years" to "not in my lifetime".

For my respondents, the European and US art markets serve as evidence that markets mature. Also, many interviewees said they were already witnessing market participants and their practices mature and become healthier. According to a star Chinese artist with ample experience abroad, local galleries "are becoming increasingly international and mature" (I54). Contemporary art knowledge is considered to be improving: according to a Beijing gallerist, "Chinese buyers are now growing up" (I34). They are more knowledgeable about art and buy more for enjoyment than investment, they speculate less, and increasingly look at exhibitions and public collections rather than at prices to determine the art value. Some interviewees said that their own organisations had matured compared to several years previously.

According to my respondents, the economic crisis resulted in more mature and healthy behaviours. Speculation was rampant and many artists cooperated directly with auctions during the art market boom in 2005-2008, but many have "learned their lessons" in the aftermath of the economic crisis as they suffered or saw others suffer due to falling prices. As a gallery manager said:

"Since the financial crisis in 2008-2009, artists have matured. Many now understand the importance of close cooperation with a gallery." (I10)

Thus, the metaphor makes actors understand the change in behaviour in terms of learned lessons and punishment for disobedient immoral behaviour. Interviewees spoke about collectors, artists, auction houses, galleries as if they were children discovering the world, figuring out what worked, and "realising" what was the "right" behavior, which broadly corresponds to the "Western system". A gallerist, aged 50, whose spouse was a collector, said about inflated prices:

"Those are probably all diseases of the early development stage. I think maybe later, as time passes, as everyone keeps acquiring art market experience, it will become more and more cool-headed and normal. Actually, Chinese people are already much more cool-headed than before." (I13)

Even concerning the illness metaphor, the actors recommend passivity, as getting better is conceptualised as inevitable. The market will become healthier on its own: many agree that the crisis has already solved many problems. One young novice collector suggested waiting: 
"I think the market is now in the self-healing period. That means we don't need others to cure us. We'll improve through internal circulation. We'll become healthier, because what happened before 2007 already taught us a very important lesson. So now we've learnt many new rules, how things should be done." (I95)

Most market actors are unsure how it will evolve exactly, as living organisms are not fully predictable. Conceptualising their market as an organism makes some market actors feel powerless, frustrated and uncertain. As a foreign-born art dealer based in Shanghai said:

"I think the whole scene is still very young, you know. We don't have so many tiers of system. We just have our first contemporary art museum that opened two weeks ago or a month ago in Shanghai. And are they even going to collect [art]? Who knows? Do they have a proper institution mentality? Who knows? It's still very early I think for the sort of macro system." (I2)

Overall, the passive attitude implies letting go, as the market and its actors should be given space to discover and evolve. One way for the market to improve, according to its participants, is to wait patiently. The emphases on time and passivity are striking because they do not feature in current theories of market emergence. The conceptual metaphor theory suggests that conceptual metaphors not only reflect perceptions, but also affect behaviour, implying a limitation to the agentic view of market development (DiMaggio, 1988).

However, conceptualizing their market as an organism makes market actors not only passive, but also responsible for its wellbeing. The developing organism metaphor implies that the market needs not only to be left alone, but also to be nurtured. These passive and active stances are not contradictory, and can often be found in the same interview. The conceptual metaphor pushes market actors towards a particular type of market-building work: it inspires the market participants to become educators and learners. As the market was conceptualised as existing, building more organisations, such as museums or auction houses, rarely came up in the interviews. Now the task was to improve, and to teach and learn how to use them. The metaphor makes actors feel responsibility to steer the market and its actors in the right direction. As an art dealer told me, "I think the maturity of the market needs to keep developing, and that's our job" (I2). My respondents never said that their "unhealthy" market needed drastic medication. Rather, they saw getting healthy as a slow process associated with behaving well and developing healthier habits.

Conceptualizing themselves as young and inexperienced inspires some market participants to learn. Auction managers said they followed Sotheby's and Christie's activities and visited their headquarters, and collectors said they undertake trips abroad to learn about the "Western" art (system). Similarly, a mainland Chinese gallerist said: 
"...from the very beginning, we did our best to learn about the healthy operation strategies and methods of Western galleries. Because in this industry, the West has been developing for several decades. And in China it has just started. So we still have a lot to learn. So if we find out about some good methods, we do our best to study them." (I12)

Viewing the market as young makes some participants, especially foreign actors and veteran local actors, assume the role of educators. As mainland collectors are conceptualised as ignorant children, they are perceived to need to be "raised", "guided" and "educated" about art and art consumption. Many galleries, with various degrees of experience and international exposure, claim that this is what they do. An experienced mainland dealer explained:

"Nobody has even basic knowledge of art. We have to make up for a missed lesson, tell them [collectors] what is good art." (I40)

Commercial organisations like galleries, art fairs and even auction houses routinely stress an educational, museum-like function that they have to take on in China. A foreignborn photography gallery owner said:

"[we] really try to be open as much as possible and [be as] accessible as possible, and I think in any gallery there is always a certain educational element, and I think here even more so. So you really have to take your time and be open and discuss with people and let them learn [...] I just think the work here [vs. the "West"] is probably greater, what one has to do, you know." (I2)

Many interviewees occupying various positions in the market, including gallery managers and art fair directors, spoke about the need to establish high-quality contemporary art museums and to educate children about contemporary art, seeing that schools provide no such education. Educating the new generation suggests the expectation of a slow change. In practice, educational activities for children are gradually introduced. During my fieldwork, UCCA, a major contemporary art institution in mainland China, set up an educational corner, where on the weekends children learn about and make art, and interact with artists.

Although galleries in different countries consider it their task to educate collectors about art and the basic art market workings, my respondents perceived the situation in China to be more urgent. One Beijing gallery, for example, organised the "Collectors' Tour" for novice collectors, including excursions to an art fair, a gallery district and an auction house. According to the gallery manager with no international ties:

"It's a great way to bring a lot of fresh collectors into this art circle. In the beginning they will maybe buy cheaper works, but in the future, if you raise them well, they may 
become big collectors in this market, and buy seven-figure artworks. Because actually they can afford it, it's just that they do not know it yet." (I21)

The idea is that when consumers have better contemporary art knowledge and fewer people buy primarily for investment, the market will become "healthier". Respondents tended to refer to the market's health in terms of the future, not the present.

The metaphor shapes actors' reactions to events and makes them appreciate foreign exposure. Asked what she thought about the Christie's auction house announcement to hold auctions in Shanghai, an art dealer anticipated a positive influence on mainland auction houses, "because it can stimulate a healthier development of the whole industry. It's clearly better than locking the door and doing abnormal things on our own" (I6).

Art world participants are educated through, among other things, lectures, discussions and role models. A female art dealer, aged 32, who runs her own contemporary art gallery, mentioned to me that she was giving a lecture about how the art market should work in a bar opened by artists in an artists' village near Beijing. She claimed it is important to explain the market workings, such as gallery representation and promotion, to artists, as they are not taught about the market at art academies. This is not usually part of the official curriculum in either Europe or the USA, and some young Chinese artists are market-savvy, which underscores that some Chinese market actors have an exaggerated perception of the ignorance in China.

Art fairs have elaborate educational programs, where speakers and moderators share their experiences and views on how the market should be organised. Entitled, for example, "What Kind of Art Scene do we Need?" (Surge art fair), they aim at promoting the "right" attitude towards art and the market. Many art fairs internationally have educational programmes, but in China the content seems more basic. Conversations concern constructing the basic market elements rather than the market's current state, or the impact of certain economic or political events. At the 2013 Art Beijing art fair, I witnessed an artist, a gallerist and a collector showcased as role models (field notes 03.05.2013). They cooperated longterm, which was portrayed as "professional". In line with the guiding conceptual metaphor, they explained the groundwork of the international art market conventions, clarified the Chinese art market shortcomings, and described what should be done and why. The interviewer summarised their lessons, for example, concerning the appropriate venues for buying art. 
Some interviewees claimed they wanted to be role models. As a gallery director who was well aware of international practices told me, he "hope[d] to set a standard, a proper one, the same as Western galleries" (I24). The conceptual metaphor makes them see setting standards and educating as difficult. A curator, as many others, complained that "raising a collector is actually very difficult" (I117). Gallerists lamented that artists ignore advice concerning "proper" practices. An art dealer claimed that "it's very hard to educate artists, hard to explain to them why it's important to have consistency [in pricing]" (field notes 22.03.2013), which is a standard art market practice.

Yet, the conceptual metaphor enthuses market actors with optimism and hope. It makes them notice positive changes and get excited about the future. A gallery owner said:

“...it's a slow developmental process. We should give it [the market] time to become healthy and mature. I think the future is promising. I am positive."

Many connect positive changes not only with gradual maturation, but also with the market actors' growing familiarity with the international environment, and the increasing wealth and stability in China. One perceived driver of change is new generations of art market participants. Many believe that as young people who studied abroad, were exposed to museums, saw artworks in regular people's homes, and who are interested in art for art's sake, return to China and become collectors, the situation will keep improving. Young art world actors educated abroad are also considered more professional. A gallerist, aged 51, explained:

"Now many-many children of people of my generation are abroad. Many of them study art, including art criticism. When they come back, it will be much better." (I25)

Although the metaphor makes market actors consider studying necessary, they think that a full imitation of foreign practices is difficult. An artist, aged 29, told me it is "no use" learning from the West, as a comparable art infrastructure is lacking in China. To some Chinese art market actors, a young market has creative potential and may develop a unique character.

\section{How did this metaphor come about?}

Why do Chinese art market participants see their market as an organism? A cultural explanation could be considered: this conceptual metaphor stems from the particular use of metaphors as communication tools in Chinese. Yu (1998) applied Lakoff's theory of metaphor to Chinese and found differences in linguistic metaphors between Chinese and English, which he argues can be explained from a cultural perspective. Others also 
acknowledge cross-cultural differences in metaphors (Cardon et al. 2005; Dodd 2002).

However, the use of linguistic and conceptual metaphors that this research identified, and the mechanism behind the conceptual metaphor, are not culture-specific. Understanding the domain of art markets in terms of the domain of organisms, including people, is an example of personification, a common way of forming a metaphor, helping us make sense of phenomena in human terms (Lakoff, 1993; Lakoff and Johnson, 1980: 33-34). Many languages have biological metaphors (Lakoff and Johnson, 1980: 47); animalisation and personification are common in Chinese (Yu, 1998: 116). The conceptual metaphor identified here may be considered an instance of a broader and deeply engrained conventional conceptual metaphor "new entities are developing organisms". It is manifested in linguistic metaphors, such as "developing" countries, markets and economies, and "(im)mature" markets or industries, which are common in both general language use and specialised financial and marketing vocabulary ("mature markets", "mature bonds") (cf. Cardon et al., 2005). This conceptual metaphor is part of a conceptual system not only in China, but also outside it. ${ }^{6}$ In addition, interviews conducted in three languages with nationals of different countries revealed the same conceptual metaphor and some of the same linguistic metaphors (e.g., "(im)mature”, "(un)healthy”, and equivalents). This means that the conceptual metaphor identified here fits with how people in China communicate generally, but it is not unique to Chinese language or culture.

Another possible explanation for the identified conceptual metaphor could be structural: the metaphor is widespread among actors with certain market roles (dealers, collectors, etc.) and market positions, for example, among those with closer ties to foreign markets. Data analysis showed that the metaphor was not limited to a particular group of actors. Artists were least inclined to generalise about the market, which is not surprising (Bourdieu, 1993). However, overall the metaphor was pervasive and was used by native Chinese and foreign respondents of both sexes, and of various ages, with various market roles, levels of commercial and artistic success and reputation, and lengths of market presence. The extent of international exposure had a minor influence on how often the metaphor emerged in an interview.

Perceptions do not only affect behavior, they are also influenced by the market's characteristics, or culture, that result from longer term processes (Lakoff and Johnson, 1980). Therefore, to understand the emergence of the conceptual metaphor, the history of the

\footnotetext{
${ }^{6}$ The relevant statements should therefore be understood not as a strategic discursive tool (Komarova, 2017), but as manifestations of a conceptual metaphor.
} 
Chinese contemporary art market and its current institutional and cultural context should be considered. This market started emerging after the reform and opening up policy in 1978, alongside other markets, and it has since been closely connected to established art markets. Local contemporary art developed after information about $20^{\text {th }}$-century artistic developments in Europe and the USA started reaching China in the late 1970s, after a period of state control of art production (Andrews and Shen, 2012). Chinese contemporary artists were first appreciated and consecrated by foreign buyers and art institutions (Kharchenkova and Velthuis, 2015). Some foreign individuals shaped China's art market by being the first to found commercial galleries and to purchase Chinese contemporary art. The main organisational forms and practices were borrowed from abroad (Kharchenkova, 2017). Thus, the conceptual metaphor "developing organism" emerged because the market is new. The market's close connection to established markets abroad explains why comparison with foreign markets is prominent. ${ }^{7}$

The political economic and cultural context also helps explain why the market actors conceptualise the broader environment in which the "organism" is embedded as bad. The state did not accept contemporary art until the 2000s (DeBevoise, 2014). During my fieldwork, although the state used contemporary art as a soft power tool, contemporary art and market did not receive support, such as tax breaks or investment in non-commercial contemporary art infrastructure (Kharchenkova, 2017). Art market regulation is lacking. Cultural consumption by the public or economic elite rarely includes contemporary art. Therefore, whereas the "developing organism" part of the metaphor is not China-specific, this conceptualisation of the environment is. Note that because the environment component did not always accompany the organism metaphor, the government is important but not central to the perception of the Chinese contemporary art market development.

Some contextual elements or events did not contribute to the metaphor, even though they may have influenced the dynamics and details of actual market development. The metaphor disguises events in the development of the Chinese contemporary art world that are usually considered key by art historians and critics, such as the Stars exhibition (1979), often described as the first exhibition of Chinese contemporary art, which was held outdoors, outside a museum, and the China/Avant-Garde exhibition (1989), which provided an overview of art from the 1980s art and was closed by the authorities after artists fired a gunshot into an artwork (Lü, 2010; Wu and Wang, 2010). These events are known to market

\footnotetext{
${ }^{7}$ The metaphor was significantly less present in interviews with members of the traditional art world.
} 
actors, but are not central to how they conceptualise the market development now. Similarly, although evidence exists of limitations on what can be exhibited in China, censorship is not reflected in the conceptual metaphor and was not central to understandings.

\section{Conclusions}

This article has explored emic understandings of an emerging peripheral market by analysing a conceptual metaphor. I have demonstrated how a guiding metaphor for the contemporary Chinese art market - "the Chinese contemporary art market is an organism" works and have discussed its implications for market (in)actions. The metaphor (a) influences how market actors communicate about their market and (b) view and justify themselves and others, and (c) it highlights problems, the future, and impacts market-building strategies. Market actors talked about rules and morality, immaturity, inexperience and childishness of themselves and others, about being accepting, patient, caring and hopeful. The marketbuilding activities, if any, were nurturing and educational. Although learning from "mature" markets was considered good, the Chinese market was not expected to become a full copy.

The contributions of this article are three-fold. First, it suggests a novel approach to studying markets through metaphor. A value of this perspective compared to other perspectives on markets and their emergence (Aspers, 2011; Fligstein and Dauter, 2007) is that it provides tools to tease out shared understandings and cognitive processes among market actors. Rather than focusing on construction of markets by powerful actors or on mutual adjustment among competing producers or on how the broader socio-economic environment, pre-existing institutions, policy or other institutional factors influence market emergence, development and functioning (Fligstein, 2001; Guthrie, 1999), this perspective puts market actors' perceptions central. I have demonstrated that metaphor analysis is an apt methodological tool within the broader family of qualitative methods to reveal shared understandings and to study sensemaking in markets. The advantage of this concrete tool compared to other qualitative approaches is that it offers a systematic way to reveal implicit assumptions and taken-for-granted ideas widely shared among a particular group as it allows us to reach beyond self-reported attitudes and offers a means to access cognitive processes. Focussing on shared understandings and their effect on behaviour, this perspective fits with both cultural and institutional approaches in sociology of markets (Powell and DiMaggio, 1991; Zelizer, 1979). 
This approach permits studying various aspects related to ideas and their diffusion in markets and cross-national differences in cognition across markets. It may help identify types of institutional work (Lawrence et al., 2009) that actors consider important to conduct for market creation and maintenance. Conceptual metaphors could be used to reveal shared understandings not only about markets overall but also about (the legitimacy of) concrete market practices, such as valuation or price-setting mechanisms (cf. Scott, 2001: 61). For emerging markets, strong shared conceptual metaphors would signify widely shared understandings and thus point to an extent of institutionalisation (cf. Fligstein, 2001; Fligstein and McAdam, 2012). As the conceptual metaphors prescribe how reality should be viewed and thus shape experiences and interactions, analysing metaphors helps explain (in)actions within markets and more generally, why particular markets operate the way they do, also beyond market emergence.

Second, this article highlights a market's emic perceptions, which are crucial to study in order to understand how markets work. It draws attention to the market actors' perspective on the market and its workings and what is salient to them, which may differ from lay or academic accounts. The organism metaphor is strikingly different from views of markets as impersonal mechanisms of supply and demand (neo-classical economists and laypeople), dehumanizing or corrupting forces (art historians and art world participants in Europe and the USA, cf. Bourdieu, 1993) and from etic metaphors used to analyse and conceptualise markets in contemporary sociology: as networks (Granovetter, 1985), structures (White, 1981), institutions (Power and DiMaggio, 1991), cultures (Zelizer, 1979), politics and social movements (Fligstein, 2001) (cf. Cardon et al., 2005). The same conceptual metaphor was identified for the market, its participants and environment, suggesting that market actors understand their market as embedded rather than abstract.

This analysis highlights limitations to the focus on agency and strategic behaviour in market construction, prevalent in economic sociology (Fligstein, 2001; King and Pearce, 2010). Particularly, a strong emphasis on passivity and waiting among the interviewees contrasts with the agentic stance in entrepreneurship literature (DiMaggio, 1982). As Chinese market actors see it, a task of a cultural entrepreneur is waiting. Although this article has focused on sensemaking rather than actual behaviour, I suggest theorising non-agentic elements of market construction, such as waiting and accumulating experience, as sources of market change. Although scholars acknowledge that institutionalisation of fields, markets and organisations takes time (Aspers, 2011; Fligstein and McAdam, 2012) and Lawrence and colleagues (2001) examined the temporal dynamics of institutionalisation, such attempts are 
few. I propose that actual and perceived time it takes for markets, and institutions within them, to institutionalise, what factors and mechanisms determine institutionalisation pace, and what patterns consequently emerge, should be studied further using a variety of empirical data. The role of time in sociology of markets and in institutional theory should be explored further.

Third, this study contributes to sociological debates on globalisation. It draws attention to emic perspectives on the global position of new markets. Whereas other scholars and journalists compare "Western" and "emerging" (art) markets, and call Chinese art world actors "immature" (e.g. DeBevoise, 2014: 163; Ho, 2008), this study shows that participants in China's market are also thinking in binary categories. They make sense of themselves visà-vis "the West" and see their market as peripheral and different from "Western" markets, which are perceived to embody the "standard". The idea that China's art market needed time to develop was expressed in the early 1990s, when the first market organisations were being established (Art\&Market). Finding a similar attitude 20 years later, when the "right" market components (types of individual actors and organisations) are present and the market enjoys considerable size, high prices and international media attention, is striking. This is also ironic, as it shows that in practice simply waiting is insufficient for market development.

Perceived inferiority aligns with Orientalist accounts (Said, 1978). However, unlike some Chinese intellectuals (Dirlik, 1996), my respondents are not self-Orientalist. Instead of seeing themselves as inherently inferior, exotic, static and stuck in fixed ancient time (Fabian, 1983), they conceptualise themselves as flexible and changing, as being in the same time, just younger. In contrast to self-Orientalism found in the Chinese tourism discourse (Yan and Santos, 2009), the art market actors have no strategic reasons to self-Orientalise. In addition, lack of self-Orientalism may suggest growing self-confidence in China.

The focus on metaphors reveals local perceptions of globalisation's tensions, in particular, perceptions of the limits to global diffusion of market institutions. Although the Chinese art market actors view "Western" markets as worth studying (DiMaggio and Powell, 1983), they perceive local unreadiness to limit institutional diffusion. Homogenisation is considered impeded until certain knowledge and stronger organisations are in place.

Exploring how actors in other new markets view themselves in relation to existing markets could be a welcome contribution to both globalisation and market literature (Velthuis and Baia Curioni, 2015). Although I cannot draw conclusions about its details and pervasiveness, there are indications that the metaphor is also used to make sense of other markets, e.g. Brazilian contemporary art market: Ocula magazine wrote about "the local 
potential of the (still immature) average local collector/visitor" and called SPArte 2014 "a clearly more mature and consolidated fair" (Belchior, 2014). In China, the contemporary art market is very closely tied with foreign markets. Yet, the developing organism metaphor could be expected in other developing markets and industries, beyond art markets, that are "catching up" with foreign counterparts, especially in developing countries where the West enjoys positive connotations, provided that the metaphor fits into the conceptual system of a local language. However, I do not suggest that any new peripheral market would necessarily have this metaphor: it is plausible that emerging markets have other key conceptual metaphors or the metaphor is modified according to the local market culture. As the health metaphor is associated with the market's rapid growth and art market boom, the health component of the organism metaphor may be absent in markets or industries that are developing slowly. Although environment could be expected to be part of the metaphor more generally, the details of the metaphor's environment component seem to be specific to the Chinese art market. In addition, as the culture of the Chinese contemporary art market changes, the conceptual metaphor can be expected to change in China as well. With this market having emerged in the last 30 years, many actors experienced and remember how it was conceived and born. Measured in lived years, this market is not only younger than the "Western" markets, it is also younger than most of its own actors. As time passes, and the market becomes older than its participants, it may outgrow the metaphor, whether or not it meets the expectations and becomes as mature as many in this market hope.

\section{Acknowledgements}

Earlier versions of this article were presented at the conferences "The Art Market in a Global Perspective" (University of Amsterdam, 2016), "Cultural Sociology Lowlands" (University of Amsterdam, 2017), as well as at Cultural Sociology research seminar at the University of Amsterdam (2015), LIAS \& LUCSoR Anthropology and Sociology Network Seminar at Leiden University (2016) and China Seminar Lecture Series at Leiden University (2017). Thanks to their participants and to Olav Velthuis, Amanda Brandellero, Giselinde Kuipers and Nataliya Komarova in particular for their helpful comments. I am also grateful to the editors and anonymous reviewers at Poetics for their suggestions.

\section{Bio}

Svetlana Kharchenkova is Lecturer at the Leiden University Institute for Area Studies (LIAS). She completed her PhD dissertation "White Cubes in China: A Sociological Study of China's Emerging Market for Contemporary Art" at the University of Amsterdam. It was part of the large-scale project "The Globalization of High Culture: How Markets for Contemporary Art 
Develop in Brazil, Russia, India and China (BRIC)", funded by the Netherlands Organization for Scientific Research (NWO). Her research interests are at the intersection of economic and cultural sociology and contemporary China.

\section{REFERENCES}

Art\&Market (1992). "A talk with artist LiHuanMing about art and market”. Art\&Market, 6, 9-10.

Abolafia, M. (1996). Making markets: Opportunism and restraint on Wall Street. Cambridge, MA: Harvard University Press.

Alexander, J. (1990). The sacred and profane information machine: discourse about the computer as ideology. Archives de Sciences Sociales des Religions, 35e Annee, 69, Relire Durkheim. 161-171.

Anand, N. \& Peterson, R.A. (2000). When market information constitutes fields:

Sensemaking of markets in the commercial music industry. Organization Science, 11(3), 270284.

Andrews, J.F. \& Shen, K. (2012). The Art of Modern China. Berkeley, University of California Press.

Aspers, P. (2011). Markets. Cambridge, Polity Press.

Beckert, J. (2010). How do fields change? The interrelations of instituttions, networks, and cognition in the dynamics of markets. Organization Studies, 31, 605-627.

Belchior, C. (2014) A report from Brazil. Ocula. https://ocula.com/magazine/reports/a-reportfrom-brazil/ Accessed 13.08.2017.

Bourdieu, P. (1993). The production of belief: Contribution to an economy of symbolic goods. In R. Johnson (Ed.), The Field of Cultural Production: Essays on Art and Literature. New York, Columbia University Press.

Cardon, M.S., Zietsma, C., Saparito, P., Matherne, B. P., Davis, C. (2005). A tale of passion: New insights into entrepreneurship from a parenthood metaphor. Journal of Business Venturing, 20, 23-45.

Cornelissen, J. P., Oswick, C., Christensen, L.T., \& Phillips, N. (2008). Metaphor in organizational research: Context, modalities and implications for research - Introduction. Organization Studies, 29(1), 7-22.

DeBevoise, J. (2014). Between State and Market: Chinese Contemporary Art in the Post-Mao Era. Leiden and Boston: Brill. 
DiMaggio, P. J. \& Powell, W.W. (1983). The iron cage revisited: Institutional isomorphism and collective rationality in organizational fields. American Sociological Review, 48(2), 14760 .

DiMaggio, P. (1982). Cultural entrepreneurship in nineteenth-century Boston: the creation of an organizational base for high culture in America. Media, Culture and Society, 4, 33-50.

DiMaggio, P. (1988). Interest and agency in institutional theory. In L. G. Zucker (Ed.). Institutional Patterns and Organizations: Culture and Environment. Cambridge, MA, Ballinger.

Dirlik, A. (1996). Chinese history and the question of orientalism. History and Theory 35(4), Theme Issue 35: Chinese Historiography in Comparative Perspective, 96-118.

Dodd, S.D. (2002). Metaphors and meaning: A grounded cultural model of us entrepreneurship. Journal of Business Venturing, 17, 519-535.

Heino, R. D., Ellison, N.B, \& Gibbs, J.L. (2010). Relationshopping: Investigating the market metaphor in online dating. Journal of Social and Personal Relationships, 27(4), 427-447.

Ho, P. (2008). Consuming art in middle class China. In C. Jaffrelot \& P. van der Veer (Eds.) Patterns of Middle Class Consumption in India and China. New Delhi: Sage.

Fabian, J. (1983). Time and the Other. How Anthropology Makes its Object. New York: Columbia University Press.

Fligstein, N. (2001). The Architecture of Markets: An Economic Sociology of Twenty-FirstCentury Capitalist Societies. Princeton and Oxford: Princeton University Press.

Fligstein, N. \& Dauter, L. (2007). The sociology of markets. Annual Review of Sociology, 33, 105-128.

Fligstein, N., and McAdam, D. (2012). A Theory of Fields. New York: Oxford University Press.

Fourcade, M. \& Healy, K. (2007). Moral views of market society. Annual Review of Sociology, 33, 14.1-14.27.

Granovetter, M. (1985). Economic action and social structure: The problem of embeddedness. American Journal of Sociology, 91, 481-510.

Guthrie, D. (1999). Dragon in a Three-Piece Suit: The Emergence of Capitalism in China. Princeton and Oxford: Princeton University Press.

Ignatow, G. (2003). "Idea hamsters" on the "bleeding edge": Profane metaphors in high technology jargon. Poetics, 31, 1-22.

Kharchenkova, S. (2017). White Cubes in China: A Sociological Study of China's Emerging Market for Contemporary Art, PhD Dissertation, University of Amsterdam. 
Kharchenkova, S. \& Velthuis, O. (2015). An evaluative biography of Cynical Realism and Political Pop. In A. Berthoin Antal, M. Hutter and D. Stark. (Eds.) Moments of Valuation: Exploring Sites of Dissonance. Oxford University Press.

King, B.G. \& Pearce, N.A. (2010). The contentiousness of markets: Politics, social movements, and institutional change in markets. Annual Review of Sociology, 36, 249-267.

Klamer, A. \& Leonard. T.C. (1994). So what's an economic metaphor? In P. Mirowski (Ed). Natural Images in Economic Thought: Markets Read in Tooth and Claw. Cambridge University Press.

Komarova, N. (2017). Ups and downs of art commerce: narratives of "crisis" in the contemporary art markets of Russia and India. Theory and Society, 46(4), 319-352.

Lakoff, G. (1993). The contemporary theory of metaphor. In A. Ortony (Ed.) Metaphor and Thought. Cambridge, Cambridge University Press.

Lakoff, G. (2003, 18 March). Metaphor and War, Again.

http://www.ugr.es/ jsantana/lies/metaphor_and_war_again.htm, accessed on 12 December 2016.

Lakoff, G. \& Johnson, M. (1980). Metaphors we Live By. Chicago and London: The University of Chicago Press.

Lamont, M. (1992). Money, Morals, and Manners: The Culture of the French and the American Upper-Middle Class. Chicago: The University of Chicago Press.

Lawrence, T.B., Suddaby, R., \& Leca, B. (2009). Institutional Work: Actors and Agency in Institutional Studies of Organizations. Cambridge: Cambridge University Press.

Lawrence, T. B., Winn, M.I., \& Jennings, P.D. (2001). The temporal dynamics of institutionalization. The Academy of Management Review, 26(4), 624-644.

Lounsbury M., Ventresca, M.J., \& Hirsch, P.M. (2003). Social movements, field frames and industry emergence: A cultural-political perspective on U.S. recycling. Socio-Economic Review, 1, 71-104.

Lü, P. (2010). A History of Art in $20^{\text {th }}$ Century China. Milan: Charta.

McAndrew, C. (2014). The Global Art Market, with a Focus on the US and China. Maastricht: The European Fine Art Foundation (TEFAF).

McCloskey, D.N. (1995). Metaphors economists live by. Social Research, 62(2), 215-237.

Meyer, J.W. \& Rowan, B. (1977). Institutionalized organizations: Formal structure as myth and ceremony. American Journal of Sociology, 83, 340-63.

Patriotta, G. \& Brown, A. D. (2011). Sensemaking, metaphors and performance evaluation. Scandinavian Journal of Management, 27, 34-43. 
Plattner, S. (1996). High Art Down Home: An Economic Ethnography of a Local Art Market. Chicago, IL: University of Chicago Press.

Powell, W.W. \& DiMaggio, P.J. (Eds.) (1991). The New Institutionalism in Organizational Analysis. Chicago, University of Chicago Press.

Said, E. (1978). Orientalism. New York, NY: Pantheon Books.

Scott, W.R. (2001). Institutions and Organizations. 2d edition. Thousand Oaks, CA: Sage.

Suddaby, R., Elsbach, K.D., Greenwood, R., Meyer, J.W., \& Zilber, T.B. (2010).

Organizations and their institutional environments - Bringing meaning, values, and culture back in: Introduction to the special research forum. Academy of Management Journal, 53(6), 1234-1240.

Velthuis, O. (2005). Talking Prices: Symbolic Meanings of Prices on the Market for Contemporary Art. Princeton, NJ: Princeton University Press.

Velthuis, O. and Baia Curioni, S. (2015). Cosmopolitan Canvases: The Globalization of Markets for Contemporary Art. Oxford: Oxford University Press.

Urry, J. (2000). Sociology Beyond Societies: Mobilities for the Twenty-First Century. London and New York: Routledge.

White, H. (1981). Where do markets come from? American Journal of Sociology, 87, $517-$ 547.

Wu, H. \& Wang, P. (2010). Contemporary Chinese Art: Primary Documents. New York: Museum of Modern Art.

Yan, G. \& Santos, C.A. (2009). "China, Forever": Tourism discourse and self-orientalism. Annals of Tourism Research, 36(2), 295-315.

Yu, N. (1998). The Contemporary Theory of Metaphor: A Perspective from Chinese. Amsterdam: John Benjamins Publishing Company.

Zelizer, V. (1979). Morals and Markets: The Development of Life Insurance in the United States. New York: Columbia University Press. 